\title{
Procalcitonin in children admitted to hospital with community acquired pneumonia
}

\author{
F Moulin, J Raymond, M Lorrot, E Marc, J Coste, J-L Iniguez, G Kalifa, C Bohuon, \\ D Gendrel
}

value for guiding treatment decisions and follow up, particularly in countries with a high frequency of Streptococcus pneumoniae strains resistant to $\beta$ lactam antibiotics.

The concentration of procalcitonin (PCT) increases rapidly in bacterial infections but remains low in viral infections. High plasma concentrations of PCT typically occur in children with bacterial meningitis or severe bacterial infections, particularly in cases of septic shock or bacteraemia, and intermediate PCT concentrations are observed in local bacterial infections. ${ }^{1-5}$ We compared the sensitivity, specificity, and predictive value of PCT, C reactive protein (CRP), white blood cell count (WBC), and interleukin 6 (IL-6) concentrations for identifying cases of community acquired pneumonia of bacterial origin in untreated children admitted to hospital as emergency cases.

\section{Patients and methods}

Of 88 patients (aged 2 months to 13 years) admitted to hospital for severe community acquired febrile pneumonia between 1 January 1996 and 1 November 1999, pathogens were identified in 72 (32 of these patients were reported in a previous study ${ }^{4}$ which ended in April 1997). We included only those children who were immunocompetent, who had no chronic disease, pulmonary or otherwise, and who had not received antibiotics in the 10 days before admission. The remaining children accounted for $60 \%$ of children examined in the emergency department for pneumonia in this period. The other patients were not included because they had already been treated, they were not subsequently admitted to hospital, or blood was not collected for PCT determination.

On admission, all patients had a body temperature above $38^{\circ} \mathrm{C}$ and a chest $x$ ray picture indicative of pneumonia, as analysed by an independent radiologist. The patients were all admitted as emergency cases on the basis of their clinical condition, assessed by the doctor in charge of the emergency department of the hospital who did not know the results of PCT determination.

Blood cultures were set up immediately and the plasma samples remaining after routine tests (CRP, WBC counts) had been carried out were frozen for later determination of PCT. IL-6 was determined in the plasma that remained after the PCT assay. We obtained the consent of parents and children for use of the available plasma for the determination of PCT and other markers. This procedure was approved by the Ethics Committee of the Cochin-Paris V Faculty of Medicine. 
Blood samples were also taken for serological testing for Mycoplasma pneumoniae, Chlamydia pneumoniae, and the principal respiratory viruses. These tests were performed on admission, and repeated two to three weeks later. Sputum samples (or pharyngeal aspiration in children below the age of 5 years) were taken from all children during a physiotherapy session to test for bacteria and viruses according to our usual procedures. Pneumonia was considered to be bacterial if more than 25 polymorphonuclear cells and fewer than 10 squamous epithelial cells per $\mathrm{ml}$ were detected by microscopy, and if cultures contained a single or a predominant microorganism, with more than $10^{6} \mathrm{CFU} / \mathrm{ml}$ in the samples. ${ }^{4}{ }^{67}$

ASSAYS

Blood samples were collected in EDTA by venepuncture. Leucocyte count was determined automatically by hospital laboratory and serum CRP was determined by nephelometry. PCT was determined from frozen samples $\left(-20^{\circ} \mathrm{C}\right)$ by an immunoluminometric assay (LUMItest PCT, BRAHMS Diagnostica, Berlin). This assay, which is specific for PCT, requires $20 \mu \mathrm{l}$ of plasma and can be completed within two hours. The detection limit is 0.1 $\mu \mathrm{g} / \mathrm{l}$. Interassay and intra-assay variations at both high and low concentrations were less than $8 \%$ and $7 \%$ respectively. ${ }^{1}$ IL- 6 was determined by ELISA (Medgenix Co.) in only 32 patients.

STATISTICAL ANALYSIS

Values from patients with pneumonia of bacterial and viral origin were compared using Student's $t$ test. The diagnostic properties of the tests were investigated by receiver operating characteristic (ROC) analysis. ${ }^{8}$ This technique summarises the validity coefficients of a test and provides an overall index of diagnostic accuracy (the area under the ROC curve) by the plotting of sensitivity against the false positive rate (one minus specificity) for all possible cut off scores. An area under the ROC curve of 0.5 is obtained if the discriminatory ability of a test is no better than chance; a value of 1.0 represents perfect discriminatory ability. Two different tests for the same patient can be compared on the ROC scale. The computer program for ROC analysis developed by Metz et al was used. ${ }^{9}$ Sensitivities, specificities, and predictive values for selected cut off points and values of disease prevalence were also assessed.

\section{Results}

A total of 88 patients were admitted for community acquired pneumonia; 16 had no pathogen identified and were not included in the study. Of the 72 patients studied, 10 (mean age 1.9 years; range $0.4-5$ years) had blood cultures positive for Streptococcus pneumoniae and 15 (mean age 3.9 years; range 0.5-14 years) had bacterial pneumonia diagnosed on the basis of bacteriological and cytological criteria ${ }^{7}$ : more than 25 polymorphonuclear cells and less than 10 epithelial cells, and cultures containing a single or a predominant microorganism, with more than $10^{6} \mathrm{CFU} / \mathrm{ml}(S$ pneumoniae in 14 and Haemophilus influenzae b in one). All these patients tested negative in serological tests for viruses, Mycoplasma, and Chlamydia, and became afebrile within 48 hours of treatment with amoxycillin (or ceftriaxone for the youngest patients).

In 37 cases, viral pneumonia was diagnosed by immunofluorescence techniques, viral cultures, or serological tests. In 29 patients (mean age 1.7 years; range $0.5-7$ years) viruses were apparently the sole cause of pneumonia (respiratory syncytial virus in eight, adenovirus in seven, influenza A virus in seven, and parainfluenza 2 or 3 viruses in seven) because bacteria were not detected in blood cultures and were not present in large numbers in the sputum. In eight other patients (mean age 1.3 years; range $0.5-5$ years), a virus was identified by serological tests, immunofluorescence, or virus culture, and there were more than 25 polymorphonuclear cells and less than 10 epithelial cells in sputum, and cultures containing a single or predominant microorganism, with more than $10^{6} \mathrm{CFU} / \mathrm{ml}$ were obtained ( $S$ pneumoniae in six, Haemophilus influenzae b in two). These eight patients were considered to have mixed bacterial and viral infections. Ten patients (mean age 6.2 years; range 3-10 years) had positive serological tests (presence of $\operatorname{IgM}$ and/or quadrupling of IgG concentrations) for Mycoplasma pneumoniae.

At admission, all patients had fever (temperature above $38^{\circ} \mathrm{C}$ ), and were admitted to the hospital based on clinical examinations by doctors in charge of the emergency department. Hypoxaemia requiring oxygen supplementation on admission was diagnosed in eight of the 10 patients with positive blood culture, in 13 of the 32 patients with bacterial pneumonia and negative blood culture, and in 19 of the 29 patients with viral pneumonia. Chest $x$ ray showed notable alveolar infiltration in 64 of the 72 patients: total lobar infiltration in 31 , and minor alveolar infiltration in 33. Interstitial infiltration was found in the eight others (virus in five, mycoplasma in two, bacterial pneumonia in one).

Tables 1 and 2 present the results for the determinations, and fig 1 shows the individual results. PCT concentration was between 2.3

Table 1 Values at hospital admission for the different groups of patients with pneumonia

\begin{tabular}{lllll}
\hline & PCT $(\mu g / l)$ & CRP $(\mathrm{mg} / \mathrm{l})$ & IL-6 $(\mathrm{pg} / \mathrm{ml})$ & WBC $\left(\times 10^{9} / \mathrm{l}\right)$ \\
\hline Bacterial pneumonia & & & & \\
S pneumoniae & & & & \\
$\quad$ Blood culture $(\mathrm{n}=10)$ & $20.5(2.3-90.6)$ & $214.4(39-400)$ & $796(95-1779)$ & $20.2(6.7-45)$ \\
$\quad$ Sputum (1 pt H influenzae $\mathrm{b})(\mathrm{n}=15)$ & $10.0(0.6-21)$ & $197(15-400)$ & $529(11-1680)$ & $23.9(10.4-42.5)$ \\
$M$ pneumoniae $(\mathrm{n}=10)$ & $1.53(0.3-4.7)$ & $103.1(10-348)$ & $156.7(45-360)$ & $13.8(6.9-26.5)$ \\
Virus + bacterial superinfection $(\mathrm{n}=8)$ & $2.68(0.6-7.6)$ & $95.2(16-249)$ & $381.6(10-1400)$ & $13.8(6.1-35.1)$ \\
Viral pneumonia (n=29) & $0.63(0.01-4.38)$ & $39.1(1-169)$ & $122(15-580)$ & $10.3(2.8-22.5)$ \\
\hline
\end{tabular}


Table 2 Validity coefficients of tests for selected cut off points in the discrimination between bacterial (including mycoplasma and bacterial + viral coinfections) and viral pneumonia

\begin{tabular}{lllllll}
\hline & Bacterial & Viral & Sensitivity & Specificity & $\begin{array}{l}\text { Pos pred } \\
\text { value }\end{array}$ & $\begin{array}{l}\text { Neg pred } \\
\text { value }\end{array}$ \\
\hline PCT $>0.5 \mu \mathrm{g} / 1$ & $41 / 43$ & $10 / 29$ & $95 \%$ & $60 \%$ & $80.3 \%$ & $88.4 \%$ \\
PCT $>1 \mu \mathrm{g} / 1$ & $37 / 43$ & $4 / 29$ & $86 \%$ & $87.5 \%$ & $90.2 \%$ & $80 \%$ \\
$\mathrm{PCT}>2 \mu \mathrm{g} / 1$ & $27 / 43$ & $1 / 29$ & $62.7 \%$ & $96 \%$ & $96.4 \%$ & $60 \%$ \\
$\mathrm{CRP}>20 \mathrm{mg} / 1$ & $38 / 43$ & $15 / 29$ & $88.4 \%$ & $40 \%$ & $71.6 \%$ & $66.6 \%$ \\
$\mathrm{CRP}>60 \mathrm{mg} / 1$ & $30 / 43$ & $7 / 29$ & $69.8 \%$ & $52 \%$ & $81.1 \%$ & $58.1 \%$ \\
$\mathrm{IL}-6>100 \mathrm{pg} / \mathrm{ml}$ & $12 / 20$ & $2 / 12$ & $66 \%$ & $83 \%$ & $85.7 \%$ & $55.5 \%$ \\
$\mathrm{WBC}>15000\left(\times 10^{6} / 1\right)$ & $28 / 43$ & $6 / 29$ & $65.1 \%$ & $79.3 \%$ & $82.3 \%$ & $60.5 \%$ \\
\hline
\end{tabular}

and $90.6 \mu \mathrm{g} / \mathrm{l}$ in the 10 cases of pneumococcal pneumonia confirmed by blood culture. It was greater than $1 \mu \mathrm{g} / 1$ in 14 of the 15 other cases with bacterial pneumonia, in six of the eight cases with viral pneumonia and bacterial
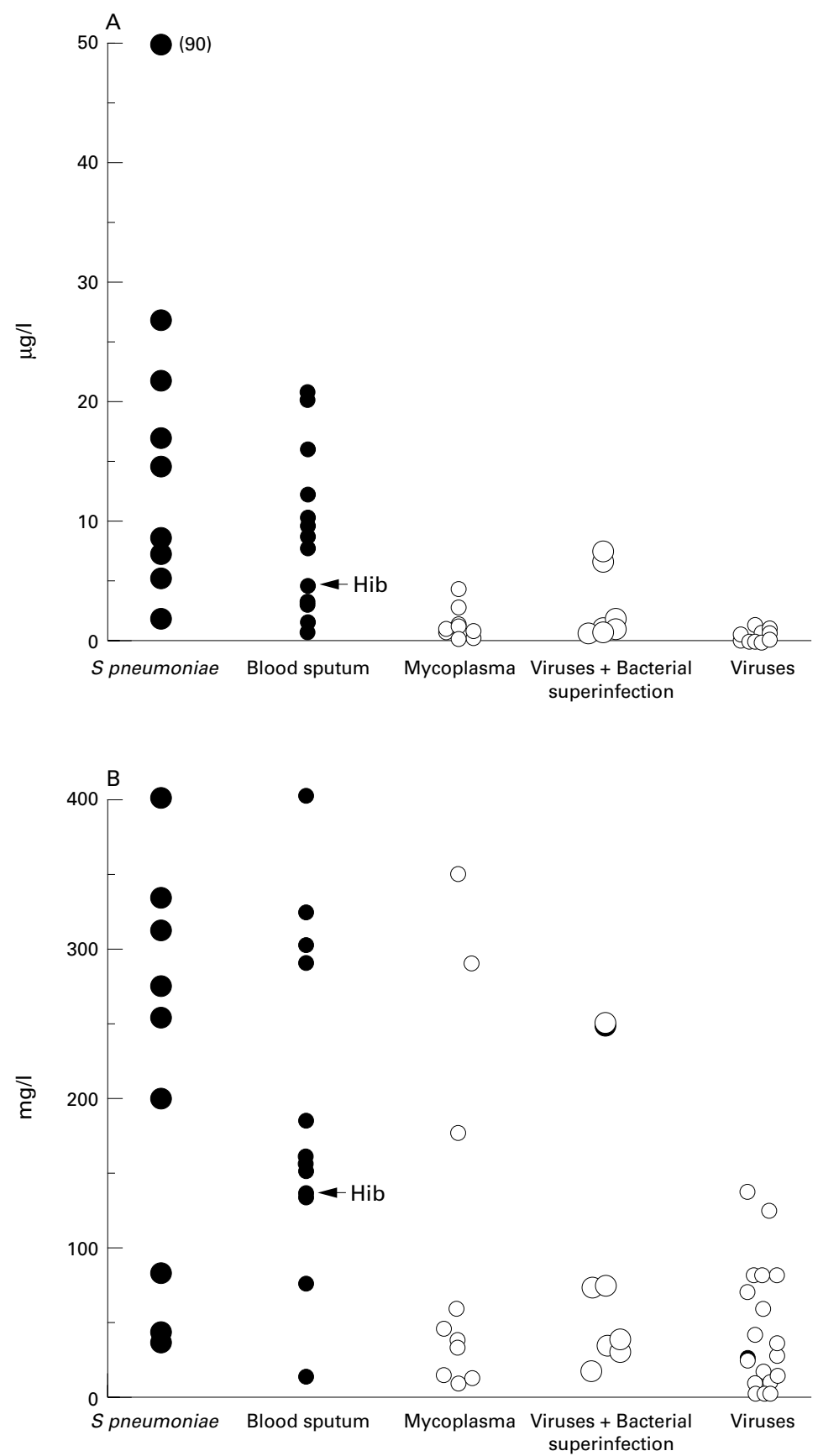

Figure 1 Individual values of PCT $(A)$ and $C R P(B)$ in the different groups of patients (one patient with haemophilus in pneumococcal group). superinfection, and in seven of the 10 cases of Mycoplasma infection. However, in four of the 29 cases with apparently isolated viral pneumonia, PCT concentration was greater than $1 \mu \mathrm{g} / 1$. In three patients PCT concentration was between 1 and $1.4 \mu \mathrm{g} / \mathrm{l}$. In a patient carrying a respiratory syncytial virus, PCT concentration was $4.38 \mu \mathrm{g} / \mathrm{l}$ and CRP was $169 \mathrm{mg} / \mathrm{l}$; no predominant bacterium was cultured in sputum.

CRP concentrations were greater than 20 $\mathrm{mg} / \mathrm{l}$ in all 10 patients with positive blood cultures (>40 mg/l in nine and $>60 \mathrm{mg} / \mathrm{l}$ in eight). In cases of isolated viral infection, CRP was greater than $20 \mathrm{mg} / 1$ in 15 of the 29 patients and above $60 \mathrm{mg} / 1$ in seven. The highest CRP concentrations in viral infections were found in patients infected with adenovirus. Considering all bacterial infections, positive blood cultures, contributory bacterial samples, secondary bacterial infections in cases of viral pneumonia, positive serological tests for anti-Mycoplasma antibodies, and isolated viral infections, we found that a CRP concentration of $20 \mathrm{mg} / \mathrm{l} \mathrm{had}$ a sensitivity very similar to that of a PCT concentration of $1 \mu \mathrm{g} / 1(88.4 \% v 86 \%)$, but a much lower specificity $(40 \% v 87.5 \%)$ for discriminating between bacterial and viral infections.

IL- 6 concentration above $100 \mathrm{pg} / \mathrm{ml}$ had a specificity of $80 \%$ but a low sensitivity. White blood cell count above $15000 / \mathrm{ml}$ discriminated poorly between bacterial and viral infections.

PCT, CRP, WBC, and IL-6 values differed significantly ( $t$ test, $\mathrm{p}<0.005$ ) between cases of bacterial and viral pneumonia. However, PCT is a better marker of invasive pneumococcal infection than CRP. Mean PCT concentration was $20.5 \mathrm{ng} / \mathrm{ml}$ in patients with positive blood cultures and $7.5 \mathrm{ng} / \mathrm{ml}$ in patients with bacterial pneumonia and negative blood cultures ( $\mathrm{p}<0.01)$; mean CRP concentration was 214 and $161 \mathrm{mg} / \mathrm{l}$ respectively (non-significant) in these two groups.

Table 2 presents the sensitivity, specificity, and positive and negative predictive values and fig 2 the receiver operating characteristic (ROC) curves. In all cases, PCT concentration differentiated viral and bacterial infections more effectively than CRP, IL-6, or WBC counts. The area under the ROC curve was 0.93 for PCT $(95 \%$ confidence interval (CI) 0.85 to 0.97$), 0.84$ for CRP $(95 \%$ CI 0.73 to 0.91 ), and 0.64 for IL-6 (95\% CI 0.45 to $0.80)$. The areas under the ROC curves were compared: $\mathrm{p}<0.04$ for PCT $v \mathrm{CRP}$, and $\mathrm{p}<0.003$ for PCT $v$ IL-6.

\section{Discussion}

Markers for the rapid identification of bacterial versus viral pneumonia in children admitted as emergency cases are particularly useful. In our study, we found that PCT is probably the most informative marker for identifying bacterial pneumonia in immunocompetent infants (not including neonates) or children in emergency departments. Clinical analysis, $x$ ray examination, laboratory test results, CRP and IL-6 determination, and WBC counts were not specific enough for the diagnosis of bacterial 


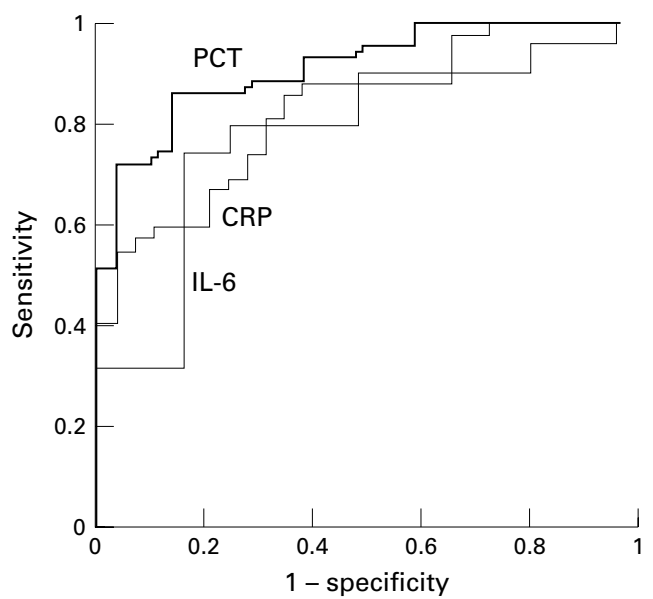

Figure 2 ROC curves for PCT, CRP, and IL-6 for discrimination between bacterial (including mycoplasma and bacterial and viral coinfections) and viral pneumonia.

pneumonia, as has been reported previously. ${ }^{610-12}$ However, invasive pneumococcal infections, bacteraemia, meningitis, and pneumonia may be severe, often leading to admission to intensive care units. ${ }^{13}$ Whatever the state of the patient, pneumococcal infections must be treated rapidly because they are life threatening; they must also be treated appropriately because resistance to antibiotics is increasing.

Blood cultures are often negative in children with pneumonia, from whom only small quantities of blood can be taken, and the paediatrician must therefore use other diagnostic procedures. The isolation of more than $10^{6} \mathrm{CFU} / \mathrm{ml}$ bacteria in a cytologically typical sputum in a context of fever and radiological pneumonia provides good evidence of a bacterial cause. Samples from children may be contaminated by oral flora, but all patients with isolated bacterial pneumonia were afebrile after 48 hours of antibiotic treatment. In a recent study, Toikka et al showed that only $6 \%$ of children with bacteraemic pneumococcal pneumonia had fever that persisted for more than 48 hours with antibiotic treatment. ${ }^{12}$

In cases of pneumococcal pneumonia, serological criteria can provide a retrospective diagnosis with good specificity and sensitivity, but validated tests for antipneumococcal antibodies and for specific immune complexes are available in only a few laboratories. In addition, they do not always distinguish reliably between pharyngeal carriage of pneumococci, acute middle ear infection, and pulmonary infection. ${ }^{14-16}$

PCT concentration was greater than $2 \mu \mathrm{g} / 1$ in all cases of pneumonia with blood cultures positive for pneumococci, and CRP was greater than $20 \mathrm{mg} / \mathrm{l}$. This cut off for CRP is too low for discrimination between bacterial and viral infections, because $40 \%$ of viral infections result in CRP concentrations above $20 \mathrm{mg} / 1$. This is consistent with previous observations. In a study by Toikka and colleagues, ${ }^{12} 32 \%$ of patients with pneumococcal bacteraemia had CRP less than $60 \mathrm{mg} / \mathrm{l}$. In a general review, Jaye and Waites ${ }^{17}$ concluded that CRP did not discriminate between bacterial and viral causes of infection of the upper or lower respiratory tract. In a recent study performed in adults, Brunkhorst et al showed that, in patients with acute respiratory distress syndrome, PCT concentration was high and in the pathological range in the group of patients with sepsis. ${ }^{18}$ They found no overlap in PCT concentration between the groups with and without sepsis, but found a complete overlap for CRP and IL-6. In this study, a PCT concentration of at least $1 \mu \mathrm{g} / 1$ provided the highest specificity and sensitivity for differentiating all bacterial causes of pneumonia from viral causes, but overlap between these two groups is not rare.

Mycoplasma infections were less frequent in this study than in a previous series because patients with these infections are admitted to hospital less frequently than those with pneumococcal or viral infections. ${ }^{6}{ }^{14}$ As previously reported in children ${ }^{4}$ and adults, ${ }^{19}$ PCT concentration increases only slightly in cases of Mycoplasma infection.

In cases of bacterial pneumonia without bacteraemia, whether primary or a complication of viral pneumonia, PCT concentration was lower than in cases with bacteraemia. Conversely, high PCT concentration in local infections seemed to be an indicator of major tissue damage, as has been shown for urinary tract infections in children. ${ }^{20}$ In this study, PCT values were significantly higher in the group with bacteraemic pneumonia than in the group with non-bacteraemic bacterial pneumonia. The difference between the CRP values of these two groups was not significant, although clinical severity, with more hypoxaemic patients, was higher in the bacteraemic group. A recent paediatric study showed that high PCT value is a marker of severe sepsis. ${ }^{21}$ In community acquired pneumonia of adults, clinical score of severity in admission was strongly correlated with PCT concentration but not with CRP concentration. ${ }^{19}$

A recent Finnish study ${ }^{22}$ reported high values of PCT in patients with bacterial pneumonia but with a large overlap between bacterial and viral pneumonia. Using PCT above $2 \mu \mathrm{g} / 1$ and CRP above $150 \mathrm{mg} / \mathrm{l}$, specificity was more than $80 \%$ for bacterial pneumonia, but sensitivity was low (50\% for PCT and 31\% for CRP). The diagnostic procedures in that study were different from those used in our study. Only one of the 126 patients was bacteraemic; bacterial pneumonia was diagnosed by tests detecting pneumolysin and $\mathrm{C}$ polysaccharide antibodies, by immunoassay, or immune complex determination. These tests may increase the number of microbiological diagnoses in carriers of $S$ pneumoniae without bacterial pneumonia. On the other hand, the majority of samples were taken after 24 hours of antibiotic treatment. PCT concentration decreases rapidly if the bacterial infection is treated, reaching normal values within one or two days, whereas CRP can increase during the first few days of antibiotic treatment. None of the children in our study was receiving treatment at the time of blood collection. There is no potential effect of age on PCT after the neonatal period. Normal values are low in infants, children, or adults, 
but reach $5 \mu \mathrm{g} / \mathrm{l}$ in normal neonates between 24 and 72 hours of life, decreasing to under 0.1 $\mu \mathrm{g} / \mathrm{l}$ after the third day. ${ }^{23}$

PCT concentration, particularly using a threshold of $1 \mu \mathrm{g} / \mathrm{l}$, differentiates between bacterial infections and viral pneumonia more effectively than CRP, WBC count, or IL-6 in emergency department situations. It is not currently possible to determine whether a patient should be given antibiotics solely on the basis of PCT concentration determination, but high values indicate the presence of pneumococcal bacteria in this study as in adults. ${ }^{19}$ PCT determination can be performed in as little as two hours with immunoluminescent tests. Rapid diagnostic tests, available at the patient's bedside, for use in emergency departments, to determine whether PCT concentration is greater than $1 \mu \mathrm{g} / 1$, would be very useful in the management of children with community acquired pneumonia.

This work was supported by a grant (CRC 97044) from This work was supported by a grant (CRC 97044) from ICAAC, San Francisco, September 1999.

1 Assicot M, Gendrel D, Carsin H, et al. High serum procalcitonin concentrations in patients with sepsis and infection. tonin concentrations in p
Lancet 1993;341:515-18.

2 Hatherill M, Tibby SM, Sykes K, et al. Diagnostic markers Hatheril M, Tibby SM, Sykes K, et al. Diagnostic markers
of infection: comparison of procalcitonin with C reactive protein 21 .

3 Gendrel D, Raymond J, Assicot M, et al. Procalcitonin in bacterial and viral meningitis in children. Clin Infect $D i$ 1997;24:1240-2.

4 Gendrel D, Raymond J, Coste J, et al. Comparison of procalcitonin with C-reactive protein, interleukin 6 and interferon-alpha for differentiation of bacterial versus vira infections. Pediatr Infect Dis ₹ 1999;18:875-81.

5 Chiesa C, Panero A, Rossi NA, et al. Reliability of procalcitonin concentrations for the diagnosis of sepsis in critically ill neonates. Clin Infect Dis 1998;26:664-72.

6 Gendrel D, Raymond J, Moulin F, et al. Etiology and response to antimicrobial therapy of community-acquired pneumonia in French children. Eur f Clin Microb Infect Dis 1997;16:388-91.
7 Wang EEL, Long SS. Acute uncomplicated pneumonia. In: Long, Pickering, and Prober, eds. Principles and practice of pediatric infectious diseases. New York: ChurchillLivingstone, 1997:250-7.

8 Campbell G. Advances in statistical methodology for the evaluation of diagnostic and laboratory tests. Stat Med 1994;13:499-508.

9 Metz CE, Wang PL, Kronman HB. ROCFIT. Chicago: Department of Radiology and the Franklin McLean Memorial Research Institute, University of Chicago, 1984.

10 Peltola H, Jaakkola M. C-reactive protein in early detection of bacteremic versus viral infections in immunocompetent and immunocompromised children. F Pediatr 1988;113: 641-6.

11 Nohynek H, Eskola J, Kleemola M, et al. Bacterial antibody assays in the diagnosis of acute lower respiratory tract infection in children. Pediatr Infect Dis f 1995;14:478-84.

12 Toikka P, Virkki R, Mertsola J, et al. Bacteremic pneumococcal pneumonia in children. Clin Infect Dis 1999;29:56872.

13 Vuori E, Peltola H, Kallio MJT, Leinonen M, Heidman K, and SE-TU Study Group. Etiology of pneumonia and other common childhood infections requiring hospitalizaother common childhood infections requiring hospitalization and parenteral

14 Ruuskanen O, Nohynek H, Ziegler T, et al. Pneumonia in childhood; etiology and response to antimicrobial therapy. Eur $\mathcal{F}$ Clin Microbiol Infect Dis 1992;11:217-23.

15 Korppi M, Leinonnen M. Pneumococcal immune complexes in the diagnosis of lower respiratory tract infection in children. Pediatr Infect Dis $\mathcal{F}$ 1998;17:992-5.

16 Heiskanen-Kosma T, Korppi M, Jokinen C, et al. Etiology of childhood pneumonia: serologic results of a prospective, population-based study. Pediatr Infect Dis f 1998;17:98691 .

17 Jaye DL, Waites KB. Clinical applications of C-reactive protein in pediatrics. Pediatr Infect Dis $\mathcal{F}$ 1997;16:735-47.

18 Brunkhorst FM, Eberhard OK, Brunkhorst R. Discrimination of infectious and noninfectious causes of early acute respiratory distress syndrome by procalcitonin. Crit Care Med 1999;27:2172-6.

19 Hedlund J, Hansson LO. Procalcitonin and C-reactive protein in community-acquired pneumonia: correlation with etiology and prognosis. Infection 2000;28:68-73.

20 Benador M, Siegrist C, Gendrel D, et al. Procalcitonin is a marker of severity of renal lesions in pyelonephritis. Pediatmarker of severity of re

21 Hatherill M, Tibby SM, Turner C, et al. Procalcitonin and cytokine levels: relationship to organ failure and mortality in pediatric septic shock. Crit Care Med 2000;28:2591-4.

22 Toikka $\mathrm{P}$, Irjala $\mathrm{K}$, Juven $\mathrm{T}$, et al. Serum procalcitonin, C-reactive protein and interleukin-6 for distinguishing bacterial and viral pneumonia in children. Pediatr Infect Dis $\mathcal{F}$ 2000;19:598-602.

23 Chiesa C, Panero A, Rossi NA, et al. Reliability of procalcitonin concentrations for the diagnosis of sepsis in critically ill neonates. Clin Infect Dis 1998;26:664-72. 